\title{
Hail events across the Greater Metropolitan Severe Thunderstorm Warning Area
}

\author{
A. A. Rasuly ${ }^{1,2}$, K. K. W. Cheung ${ }^{1}$, and B. McBurney ${ }^{1,3}$ \\ ${ }^{1}$ Department of Environmental Sciences, Macquarie University, Australia \\ ${ }^{2}$ Department of Climatology, University of Tabriz, Iran \\ ${ }^{3}$ Weatherzone, New South Wales, Australia \\ Correspondence to: K. K. W. Cheung (kevin.cheung@mq.edu.au)
}

Received: 23 June 2014 - Published in Nat. Hazards Earth Syst. Sci. Discuss.: 18 November 2014

Revised: 19 April 2015 - Accepted: 23 April 2015 - Published: 13 May 2015

\begin{abstract}
This study addresses the recent climatology of hail occurrence in the Greater Metropolitan Severe Thunderstorm Warning Area (GMSTWA) of New South Wales (NSW). The study area is a sprawling suburban area with a population of nearly 4.7 million and one of Australia's largest metropoles. The main objective is to highlight the recent temporal-spatial fluctuations of hail event frequencies and magnitudes (sizes) for each of recognized and vastly inhabited local government areas (LGAs). The relevant hail event data from 1989 to 2013 were initially derived from the severe storm archive of the Australian Bureau of Meteorology. A climatologically oriented GIS technique was then applied in the examining and mapping procedure of all hail events and hail days reported throughout the study area. By applying a specific criterion, severe hail (defined as $2 \mathrm{~cm}$ or more in diameter) was cautiously selected for relevant analysis. The database includes 357 hail events with sizes $2-11 \mathrm{~cm}$ which occurred in 169 hail days (a day in which a hail event at least more than $2 \mathrm{~cm}$ reported) across the region during the past 25 years.

The hail distribution patterns are neither temporally nor spatially uniform in magnitude throughout the study area. Temporal analysis indicated that most of hail events occur predominately in the afternoons with peak time of 1-5 p.m. Australian eastern standard time (EST). They are particularly common in spring and summer, reaching maximum frequency in November and December. There is an average of 14.3 events per year, but a significant decreasing trend in hail frequency and associated magnitude in the recent years has been identified. In turn, spatial analyses also established three main distribution patterns over the study area which include the Sydney metropolitan, the coastal and the most
\end{abstract}

pronounced topographic effects. Based on the understanding of the favorable factors for thunderstorm development in the GMSTWA, the potential impacts from climate variability and future climate change have been briefly discussed.

\section{Introduction}

In Australia, severe thunderstorms are defined as those that produce any of the following four weather phenomena: hail with a diameter of $2 \mathrm{~cm}$ or more, wind gusts of $90 \mathrm{~km} \mathrm{~h}^{-1}$ or greater, tornadoes and flash flooding (BoM, 2011). Hail events likely produce dissimilar categories of damages to the natural environment and often disastrous consequences upon people in the region (Griffiths et al., 1993; Allen et al., 2011). Severe hailstorms are localized events which could affect smaller areas and are responsible for everlasting damages (Alford, 1994; Johnson et al., 1995). Such storms dangerously influence communities across the region every year, causing fatalities, destroying properties and crops and disrupting businesses (Middelmann, 2007). Across the Greater Metropolitan Severe Thunderstorm Warning Area (GMSTWA), each year severe hailstorms damage urban infrastructures and properties worth more than AUD 100 million (DECCW, 2010). These storms can far exceed maximum hail sizes larger than $7 \mathrm{~cm}$ and sometimes cause injuries and even deaths (EMA, 2009). In the past, many hail events were reported from the Sydney metropolitan area, a densely populated area (Mitchell and Griffiths, 1993; Schuster et al., 2005). It is reasonable to state that many other areas of New South Wales (NSW), in particular the remote coastal 
and mountainous areas, are equally if not more at risk from these destructive hail occurrences (Natural Disasters Organisation, 1989; Leigh and Kuhnel, 2001).

In the context of NSW, many hail events were documented in the literature (Zillman, 1999). The majority of such research documents described individual severe or damaging hailstorms in the Sydney region and NSW (Alford et al., 1995; BoM, 1995a, 2006). Some others highlighted several properties of hail events at local or regional scales, targeting urban and agricultural areas (Morgan, 1979; Hannay and Wilson, 1994; McMaster, 2001).

Furthermore, hail climatology in Australia and NSW has been studied in details by some meteorologists and climatologist in the past decades. For example, Grace et al. (1989) generated severe thunderstorm climatology for southern Australia, and Harper et al. (2001) discussed severe thunderstorm risks in southeast Queensland. A climatology for NSW by Griffiths et al. (1993) provided details on the atmospheric phenomena associated with severe thunderstorms. Schuster et al. (2005) described hail climatology of the Greater Sydney Area and NSW. They found that the most active hailfall regions are located in the northern NSW and Sydney's most densely populated suburbs. On the whole, it was found that severe thunderstorms in the region impose distinct daily and seasonal distributions, similar to those in many parts of the world, with maxima in the warmer months (October to February) and during the late afternoon. A few examples of such major hail events are given in Table 1 . These events have been selected because they imposed the foremost disastrous and costly impacts on the natural environment and human society in the region (DECCW, 2010).

The current paper describes the climatology of more recent hail events in the GMSTWA by analyzing hail reports from 1989 to 2013. Parameters analyzed include hail frequency, hail days and hail magnitudes (sizes) in the local government areas (LGAs) during the last 25 years. Based on the created data sets, different temporal patterns on the diurnal, monthly, seasonal and yearly timescales were firstly addressed. Secondly, to visualize the spatial distributions of hail occurrence in different LGAs, some GIS functions were applied and the relevant digital layers were generated in the associated software setting. Emphasis was given to model all temporalspatial fluctuations in order to identify the overall trends in the hail data set. This was done based on an adjusted Tornado and Storm Research Organisation (TORRO) Hailstorm Intensity Scale in recognizing the hazardous LGAs within the GMSTWA (Webb et al., 1986).

\section{Climatic characteristics}

The GMSTWA is located on the southeastern coast of NSW in the vicinity of the Tasman Sea. It includes the Sydney metropolitan area, which is expanding rapidly inland and contains highly industrialized pockets, consisting of the Syd-

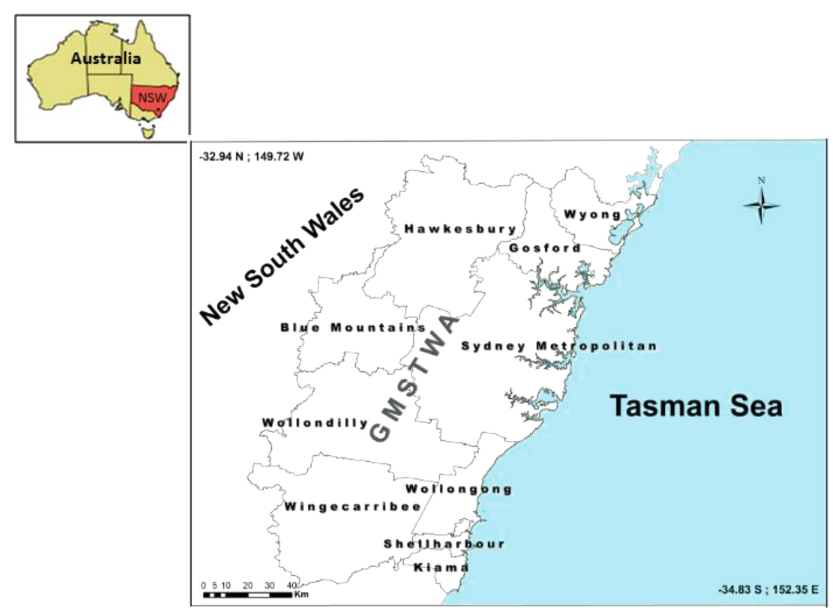

Figure 1. The location map of the study area.

ney metropolitan, Wollongong, Shellharbour, Kiama, Wingecarribee, Wollondilly, Blue Mountains, Hawkesbury, Gosford and Wyong LGAs (BoM, 2012a). The GMSTWA is defined by the Bureau of Meteorology (BoM) as a particular warning area in which severe thunderstorm warnings can be issued whenever severe thunderstorms are occurring in an area or are expected to develop or move into the area during the ensuing few hours. Such a sprawling suburban area, with a population of approximately 4.7 million, is Australia's oldest and the most populated region. The geographic location of the study area is shown in Fig. 1.

The climate of the study area could be classified as being temperate with cool to cold winters and warm to hot summers (Sumner, 1983). Generally the climate of this region arises from a complex interaction of synoptic scale regional and local controls (Ryan, 1992; Kounkou et al., 2009). On the synoptic scale the region is under the influence of mainly drier westerly airstreams in the winter and predominantly moist easterly air streams in the summer months (Linacre and Hobbs, 1977; Knight and Knight, 2001; BoM, 2012b). Each year, many thunderstorms occur in the region, some of which are strong enough to produce one or more of disastrous costly effects in the GMSTWA (Kuleshov et al., 2002; Davies et al., 2008). However, hail events have been previously observed at intensities so powerful that they could cause extended and disastrous damages to the GMSTWA's environment and communities (BoM, 1993; Davies et al., 2008).

\section{Data and methodology}

\subsection{Data selection procedure}

Many thunderstorms occur each year throughout the GMSTWA (BoM, 2011). Although all thunderstorms produce lightning, tornados, gusty winds and hail that are dangerous themselves, not all of them are "severe" or likely 
Table 1. Examples of major hailstorms reported in the GMSTWA extracted from the hail GIS database.

\begin{tabular}{|c|c|c|c|c|}
\hline $\begin{array}{l}\text { Date } \\
(1989-2013)\end{array}$ & Nearest town & $\begin{array}{l}\text { Weather } \\
\text { forecast district }\end{array}$ & $\begin{array}{r}\text { Maximum } \\
\text { Hail Size }(\mathrm{cm})\end{array}$ & $\begin{array}{l}\text { Intensity category and } \\
\text { Estimated costs } \\
\text { AUD millions of dollars (MD) }\end{array}$ \\
\hline 18 Mar 1990 & Liverpool and Bankstown & Sydney metropolitan & 8 & Super hailstone, $400 \mathrm{MD}$ \\
\hline 21 Jan 1991 & Turramurra and Duffys Forest & Sydney metropolitan & 7 & Very destructive, $560 \mathrm{MD}$ \\
\hline 14 Apr 1999 & Surry Hills & Sydney metropolitan & 9 & Super hailstone, 1.7 Billion \\
\hline 3 Nov 2000 & Yennora and Greystanes & Sydney metropolitan & 7 & Very destructive, unknown \\
\hline 9 Dec 2007 & Sydney suburbs & Sydney metropolitan & 11 & Super hailstone, $470 \mathrm{MD}$ \\
\hline
\end{tabular}

Table 2. An adjusted TORRO Hailstorm Intensity Scale (H3 to H10) for the GMSTWA hailstones.

\begin{tabular}{llrl}
\hline Size code & Intensity category & Size (diameter in $\mathrm{cm})$ & Typical damage \\
\hline $\mathrm{H}_{3}$ & Potentially severe & $2-3.1$ & severe damage to gardens, trees, plants and crops \\
\hline $\mathrm{H}_{4}$ & Severe & $3.2-4.1$ & $\begin{array}{l}\text { widespread glass, skylights, likely damages to buildings } \\
\text { and cars }\end{array}$ \\
\hline $\mathrm{H}_{5}-\mathrm{H}_{6}$ & Destructive & $4.2-6.1$ & $\begin{array}{l}\text { widespread destruction of trees and roofs; risk of injuries } \\
\text { and serous damages to cars; aircraft bodywork dented and } \\
\text { brick walls pitted }\end{array}$ \\
\hline $\mathrm{H}_{7}-\mathrm{H}_{8}$ & Very destructive & $6.2-7.7$ & $\begin{array}{l}\text { severe roof damage; risk of serious injuries } \\
\text { and severe damage to all buildings and city structures }\end{array}$ \\
\hline $\mathrm{H}_{9}-\mathrm{H}_{10}$ & Super hailstones & $7.8-14$ & \begin{tabular}{l} 
extensive structural damages and could cause fatal injuries \\
\hline
\end{tabular} \\
\hline
\end{tabular}

to produce intense hail occurrences in the region (McBurney, 2012). According to BoM (2012a), severe thunderstorm hail events are defined as those equal to or larger than $2 \mathrm{~cm}$. Colquhoun (1972) and Rasuly and Cheung (2013) indicated that thunderstorms are typically strongly skewed in space, occasionally with extremely intense localized events. The estimation of the temporal-spatial distribution of hailstorms might be biased by these cases, particularly where there are missing data or is a lack of a dense hail-pad network in the region (Zillman, 1999). The present study examines only the distribution of hail events (frequency and size observations) within the long period in the spatial context of a defined thunderstorm warning area rather than analyzing hail-pad data.

Accordingly, all hail events were extracted from the BoM Severe Storms Archive, which contains information relating to recorded severe hail events, their geographic coordinates and relevant temporal attributes. In the data extracting process, a related interface device was first used to query the appropriate database. Then, all matched data were transferred to a worksheet and subsequently processed into an ArcGIS setting (Mitchell, 2005). According to BoM (2011), using these sorts of data may result in different kinds of limitations, namely completeness of data and lack of recorded observations in particularly unpopulated areas. To avoid such errors in the data and analyze only the severe hail events across the region, the observations were constrained through a num- ber of quality assurance processes. Primarily all observations recorded with incomplete records were removed from the data set and only records with hail equal or larger than $2 \mathrm{~cm}$ have been chosen. In the final data-matching procedure, all observations were cautiously verified with the BoM's significant weather and monthly weather review reports.

\subsection{Techniques applied}

From the Australian Severe Storms Archive, hail records were first selected because of their qualified accuracy and the current study aims. By creation of the main database, it was possible to find out the fundamental temporal-spatial patterns in the data across the GMSTWA framework at a GIS setting (Illian et al., 2008; Lauren and Mark, 2010). Based on an adjusted TORRO Hailstorm Intensity Scale to hail events, it was assumed that hail events larger than $2 \mathrm{~cm}$ in size could enforce potentially severe super hail that would cause the most possible damage to the plants, crops and buildings. To illustrate the existing data based on the intensity categories, relevant hail magnitudes have been merged for a straightforward mapping purpose (Table 2).

To gain an appreciation of the longer-term variability of hail frequency, the yearly data were analyzed by applying a normalized residual mass curve (NRMC). The NRMC is defined as the accumulated difference between the actual annual hail days for each year and the mean annual observa- 


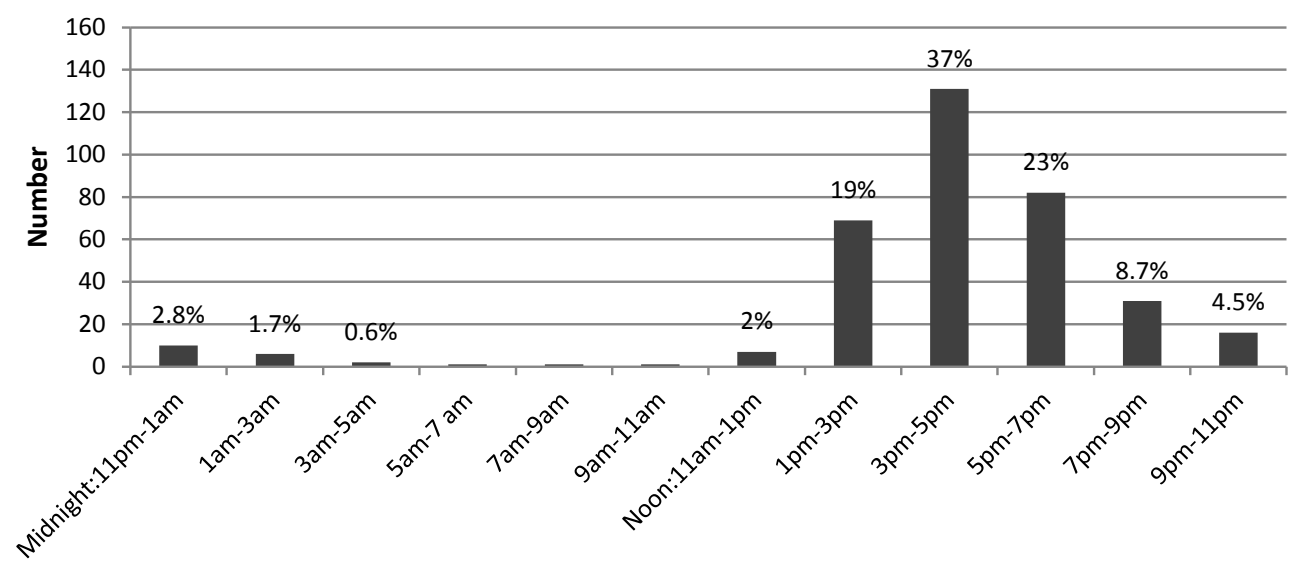

Hour (EST)

Figure 2. Diurnal distribution of hail events in the GMSTWA during 1989-2013.
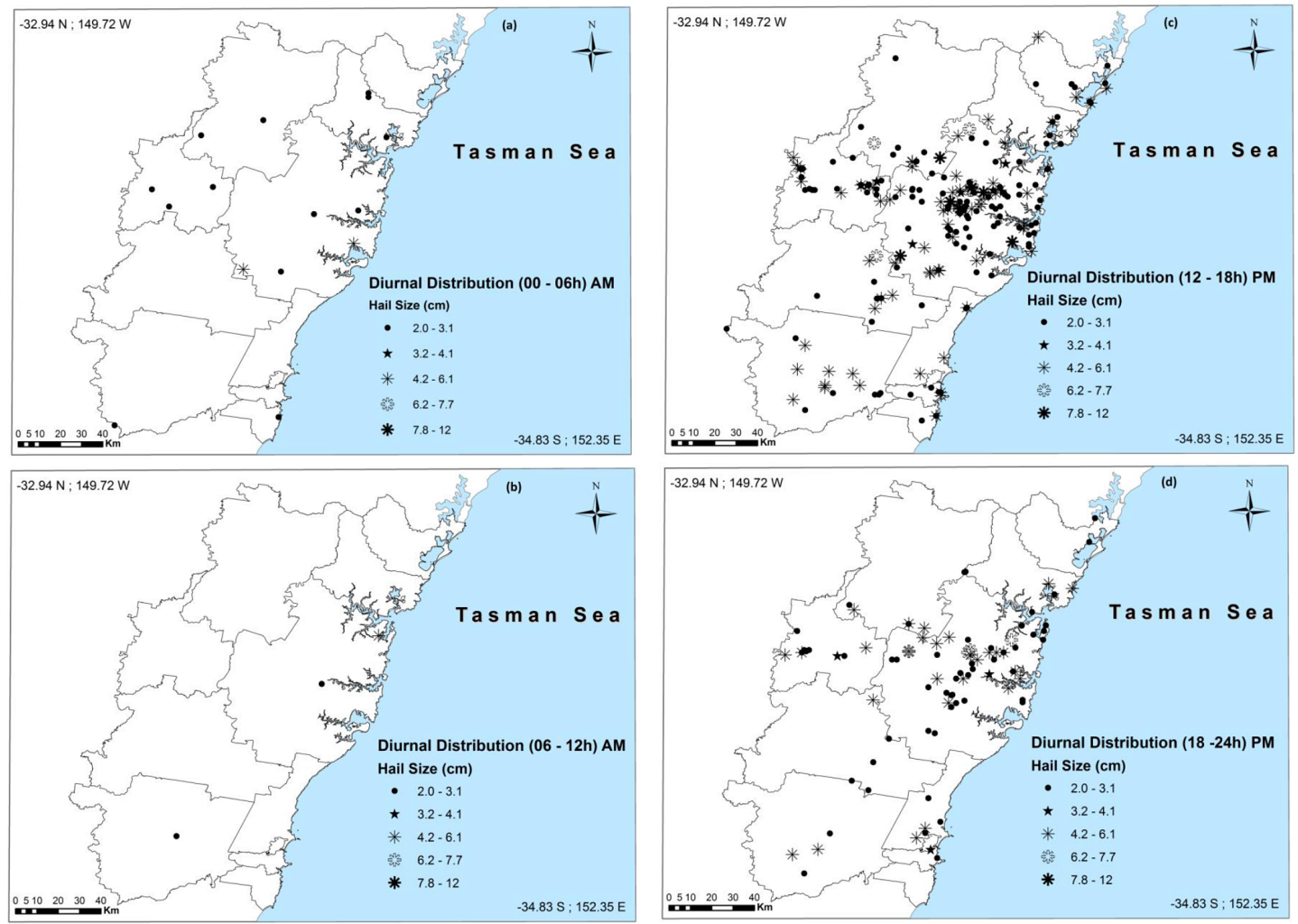

Figure 3. Spatial distribution of the hailstone events in the GMSTWA during (a) 00:00-06:00 a.m., (b) 6 a.m.-12 p.m., (c) 12-6 p.m. and (d) 6 p.m.-12 a.m.

tions over total years of the record, divided by the mean of these numbers (BoM, 1991). For generalizing the geographic locations of hail occurrence over the entire area, a kernel density interpolation estimator was introduced (Gatrell, 1994). Basically, a kernel density tool calculates the density of point features such as hail occurrence location in a search radius around all similar features. Conceptually, a smooth curved surface is fitted over each incident hail point in kernel den- sity procedures regarding all hail observations (Gatrell et al., 1996). The surface value is highest at the location of the occurrence point and diminishes with increasing distance from the point, reaching 0 at the search radius distance from the point (Silverman, 1986).

In the final generated maps, the hail size field was used to weigh certain observations greater than others, depending on their locations in the geographic context of the study area. 


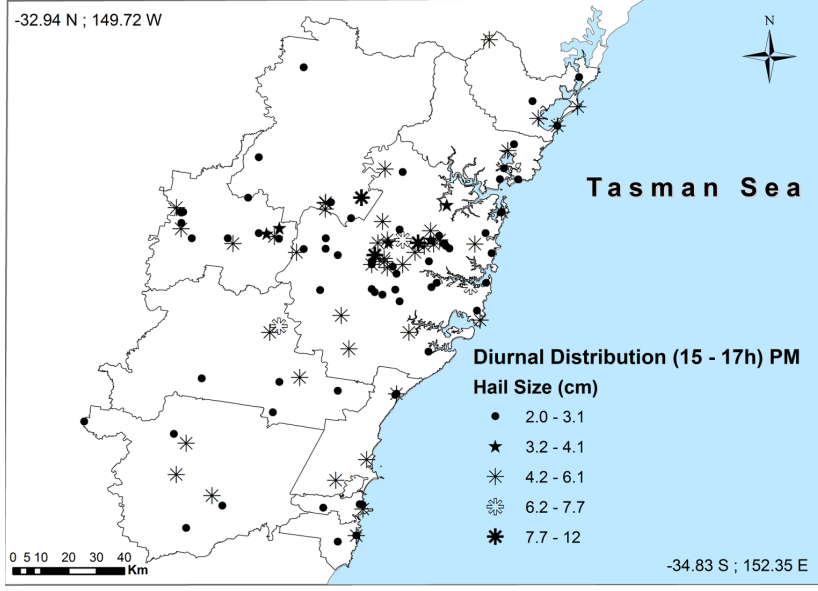

Figure 4. Spatial distribution of the hail events for peak time occurrences.

The general form of the kernel density estimator is

$\hat{f}_{\lambda}(x)=\frac{h v}{n \lambda} \sum_{i=1}^{n} K_{0}\left(\frac{x-x_{i}}{\lambda}\right)$,

where $K_{0}($.$) is the kernel function, \lambda$ is the bandwidth, $n$ is the sample hail size, $x_{i} h$ outlines the smoothing factor and $v$ specifies the vertical scaling factor. More details on the subject could be found in the relevant sources (Scott, 1992; Scott et al., 2000). All the above-mentioned spatial analyses were settled and executed in a model builder framework, as automated in the standard ArcGIS software (Scott and Getis, 2008; Rasuly, 2005).

\section{Results}

\subsection{Diurnal patterns and monthly variability}

As a result of frequent passages of different air masses and effects of climatic parameters in unstable atmospheric conditions, the GMSTWA experiences a wide variety of severe hailstorms in all seasons. Usually, warmer months have thunderstorms with severe hailstorms, some of them deadly and often quite damaging to the environment, crops and property (Spark and Casinader, 1995). The goal of the current section is to present information on diurnal and monthly scales and their associated spatial distribution characteristics.

All events ranging from a hail size of 2 to $12 \mathrm{~cm}$ were selected and for the purposes of the current study placed into $2 \mathrm{~h}$ bins based on EST. As it is shown in Fig. 2, there is a marked daily distribution of hail frequency during the afternoons peaking between 3 and 5 p.m., with 131 events and nearly $37 \%$ of all observations. A vast majority of severe hail events (79\%) occurred between 1 and 7 p.m. during the peak surface heating hours in the region. An additional $13 \%$ of all severe hail events occurred during the early to late evening

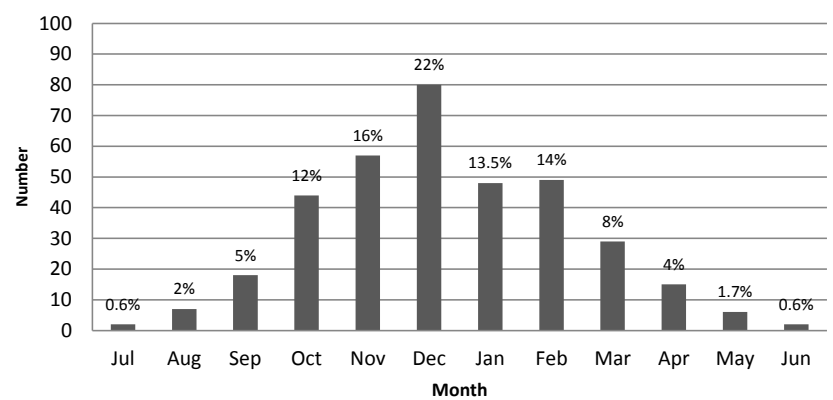

Figure 5. Monthly distribution in percentage of hail frequency in the GMSTWA.

hours (7 to 11 p.m.) when instabilities are still high. A minimum number of events (about 4.5\%) occurred from 1989 to 2013 overnight (11-1 a.m.). Seemingly, the chance of hail occurrence during early morning ( 3 a.m.) until 11 a.m. is very low: less than $3.5 \%$ of all events. As Batt et al. (1995) indicated, in Australia, although hail can occur at any time of the day, it mostly falls in the afternoon periods.

Figure 3 shows spatial distribution of the hail events in the GMSTWA for different daily time periods. It can be seen that hail ranging from 2 to $12 \mathrm{~cm}$ occurred throughout the study area, while larger hail was also widespread in the GMSTWA, particularly in the Sydney metropolitan and Blue Mountains LGAs.

The spatial distribution of hail events during the peak time occurrence (3-5 p.m.) is shown in Fig. 4. Nearly 131 hail events have been reported within this peak period inside the LGAs. The majority of larger-sized observations (more than $6 \mathrm{~cm}$ ) were reported from the study area, somewhere inside the Sydney metropolitan, southern Hawkesbury and Wingecarribee LGAs, whereas small-size hail events could be seen throughout the GMSTWA. Undoubtedly, the level of damage largely depends on other accompanying severe thunderstorms events (gusty winds or very intense thundery rains), which possibly occurred in the period of individual hailstorm events (Bahr et al., 1973).

Over a longer timescale, the monthly distribution of hail events shows a marked pattern throughout the year (Fig. 5). There is a distinct tendency for all thunderstorms to occur during the months of September through March. This period is normally referred to as the severe thunderstorm season in the region (BoM, 1995b). The increase in storms during this period is primarily due to the increase in energy provided by the sun during the warmer spring (September-October-November) and summer (DecemberJanuary-February) months, coupled with timely synoptic weather patterns that are favorable for storm growth (Matthews and Geerts, 1995; Matthews, 1996). Of the hail diameter exceeding $2 \mathrm{~cm}$ across the GMSTWA, nearly $33 \%$ of the reports occurred from September through November (spring) and $49.5 \%$ from December to February (summer). December is the peak month for the occurrence of severe 

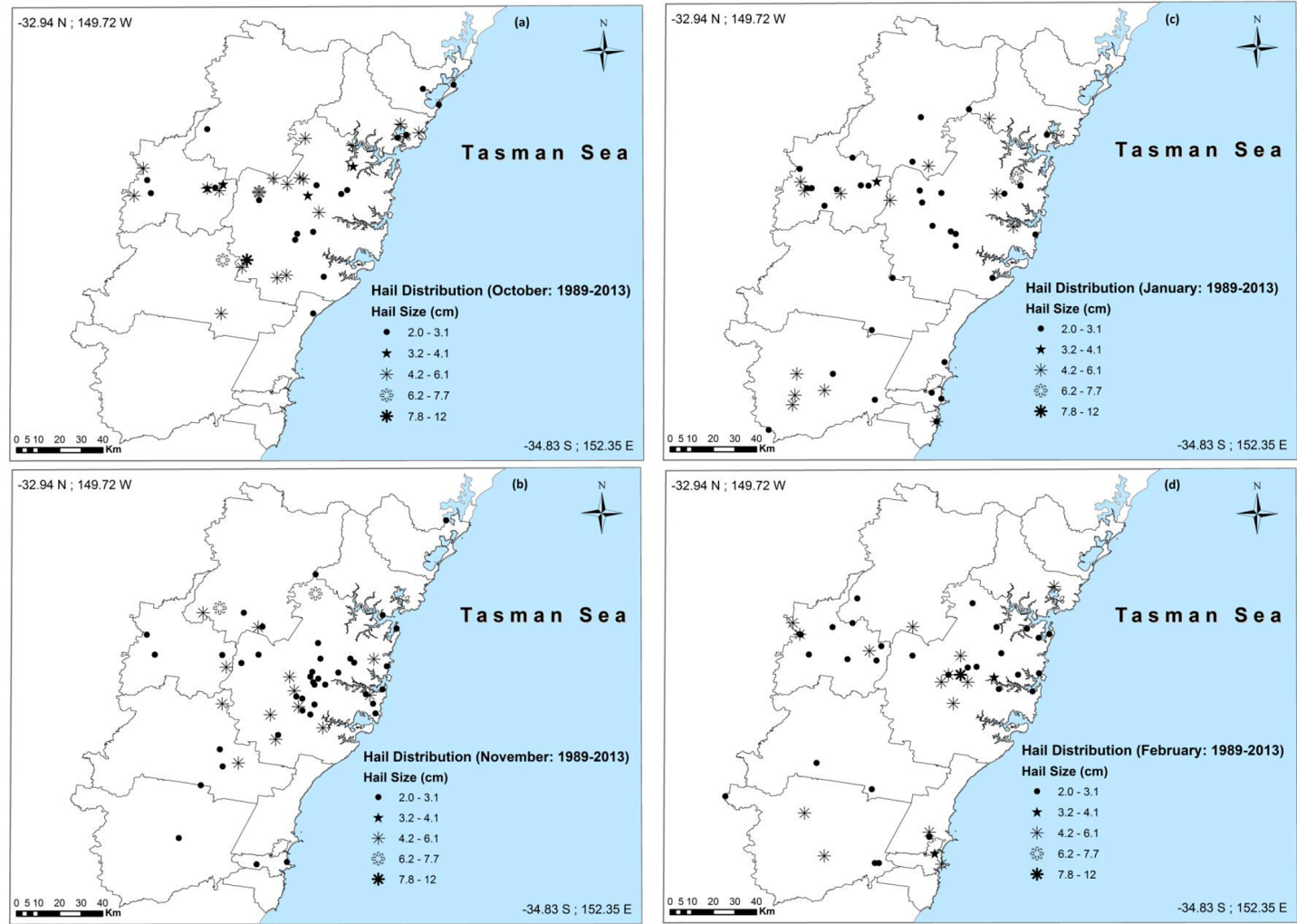

Figure 6. Spatial distribution of hail events during the warm months of (a) October, (b) November, (c) January and (d) February.

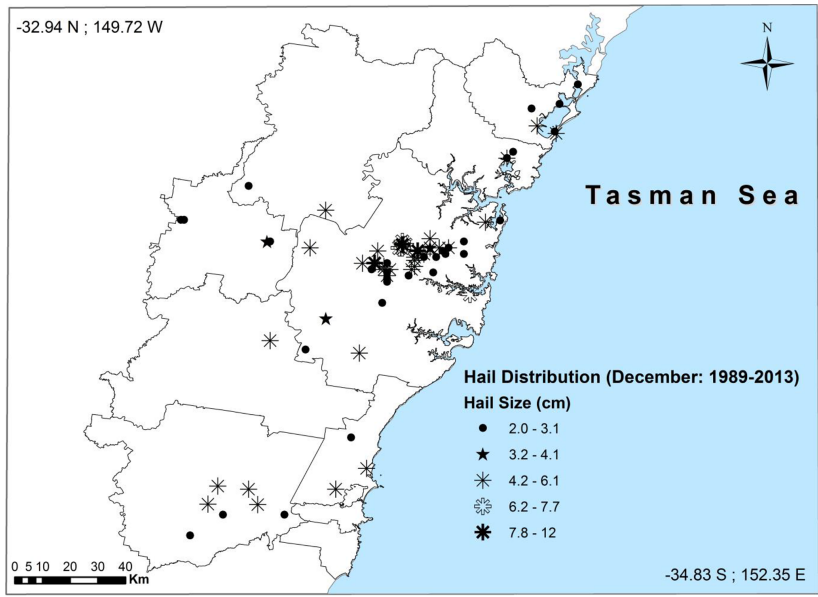

Figure 7. Spatial distribution of hail events during December with the maximum observations recorded inside the study area.

hail with $22 \%$ of the events reported. May through August is the least likely time to expect severe hail, with only 17 events. Meanwhile, March and April as transitional months have considerable hail events with more than $12 \%$ of observations. Regularly, the warm months (October to February) dominate the hail activities.
As shown in Fig. 6, a large spatial variability of hail occurrence was distinguished in the GMSTWA during the warm months (October, November, January and February), with maximum hail observed in the Sydney metropolitan and Blue Mountains and a general decreasing tendency towards to the west of the study area. An increasing tendency of hail frequency and sizes can be noticed from October to November. In a similar manner, it was found that in January, February and even March (as the first month of autumn) the frequency and range of hail are higher in the Sydney metropolitan and the southwestern parts of the GMSTWA. The majority of hail events were observed in the Sydney metropolitan area in December, mainly reported from the southwest to northeast (Fig. 7). There are nevertheless considerable dissimilarities in hailstone size reported from the study area.

\subsection{Seasonal to interannual variability}

As is shown in Fig. 8, there is a considerable seasonal variation in hail events inside the GMSTWA. As expected, in response to the warm climatic environment and unstable atmosphere, hailstorm activity is highest during spring (September-November) and summer (December-February) and weakest during autumn (March-May) and winter (JuneAugust). For the entire GMSTWA the maximum hail events occur in the late spring and early summer; however, there 

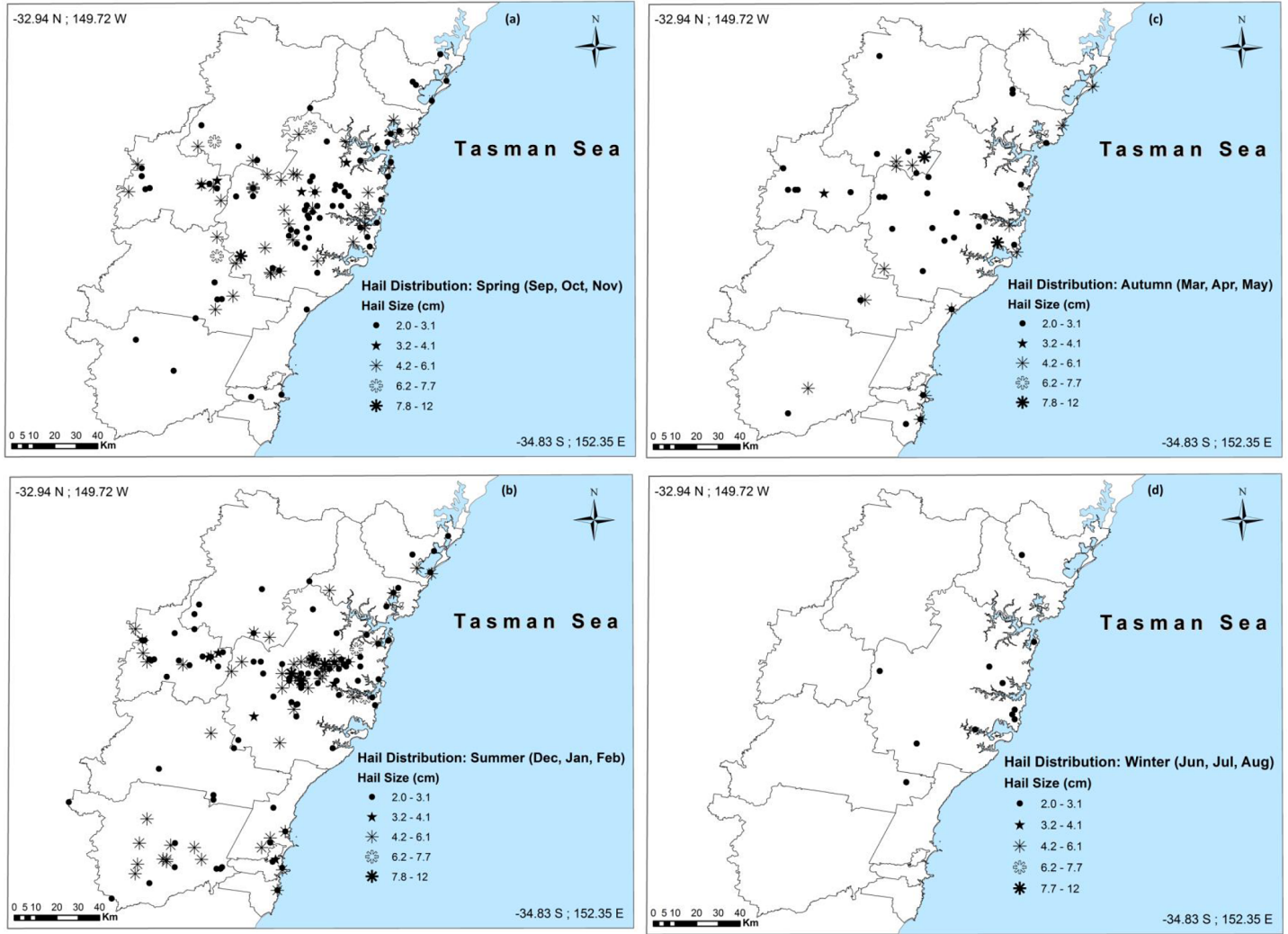

Figure 8. Seasonal distribution of hail events during (a) spring, (b) summer, (c) autumn and (d) winter.

are considerable differences within the 10 LGAs. In spring nearly 119 hail events $(33.3 \%)$ have been reported in the region. The hail sizes range between 2 and $12 \mathrm{~cm}$ with an average of $3 \mathrm{~cm}$. In summer, the number of hail events increases to $177(49.6 \%)$; the maximum of $11 \mathrm{~cm}$ of hail was reported from the Sydney metropolitan area. In contrast, in autumn $(14 \%)$ and winter $(3 \%)$ the study area received fewer hail events and very small hail sizes. On average, a higher number of hail events is expected to occur in the Sydney metropolitan, Blue Mountains and Wingecarribee.

The annual frequency of hail events and associated days reported in the GMSTWA is shown in Fig. 9a. A comparison of the number of years above and below the averages indicates that there is a fluctuating pattern with high and low years. For example, from 2000 to 2005 and more significantly in 2007 , a considerable number of hail events has occurred in the region. In contrast, the number of hail events was significantly reduced after 2009 with less than 5 events. Likewise, the frequency of hail days has an average number of 6.8. A maximum of 12 hail days occurred in 2001, while the second maximum of 11 was recorded in 2008. However, a significant drift in hail days is prominent during the recent years in the study area. It could be argued that the existence of a speckled relationship between hail frequency and associated hail days may be explained by the skewed nature of thunderstorms and indeterminate observation policy in the region (Tucker, 2002). As the results of other researchers indicated, thunderstorm events are typically strongly skewed in space, occasionally with extremely intense localized events (Colquhoun, 1972; Shepherd and Colquhoun, 1985; Rasuly, 1996).

To model the longer extent variability of hail days, the yearly data were examined by applying a NRMC offered by BoM (1991). The NRMC is defined as the accumulated difference between the actual annual hail days and the hail days for each year and the mean annual observations over total years of the record, divided by the mean of these numbers. A NRMC model was fitted for the GMSTWA's hail events reported from 1989 to 2013 . Figure $9 \mathrm{~b}$ clearly shows sequences of high and low occurrence of hail during the time.

Figure 10a indicates the spatial pattern for hail events in different LGAs reported from 1989 to 2013. Mostly, the higher number of hail events and the largest magnitudes were frequently reported from the Sydney metropolitan, Blue Mountains and noticeably the southern and northeastern part of the study area. Hence, in a broad extent the hail frequency and associated sizes are not at all evenly distributed throughout the study area. In a geographic context of the GMSTWA, the overall pattern of hail occurrence can be identified in regard to the LGA boundaries by Fig. 10b. In an area-averaged model the total number of hail events for each LGA is shown. It is clear that many hail events were observed in the cen- 


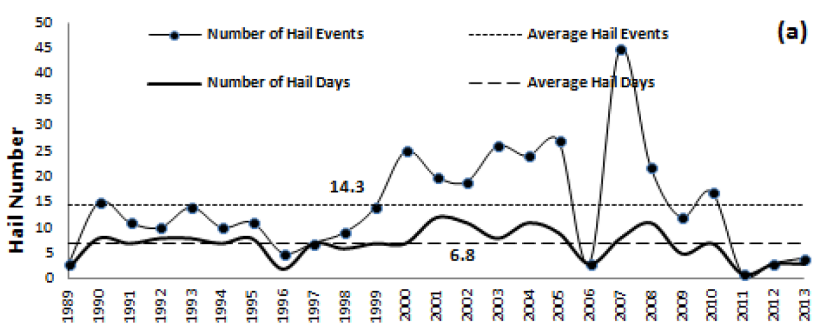

Year

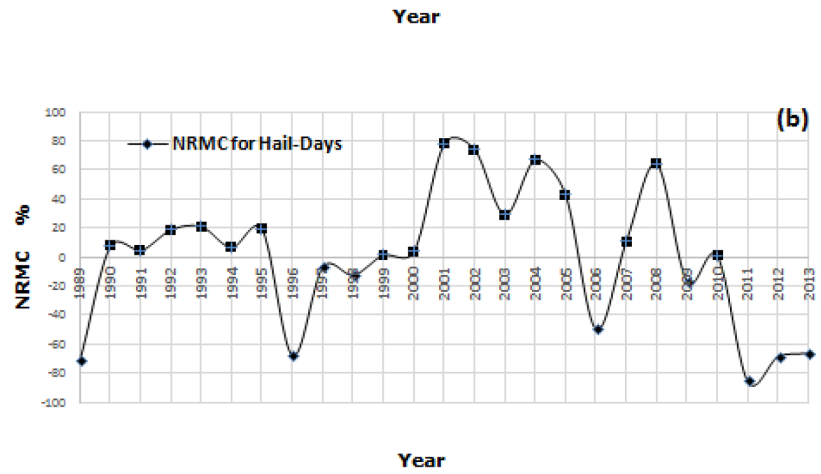

Figure 9. (a) Time series of the hail events (all severe hail reports inside of the study area per year) and associated hail days (days in which at least one severe hail event larger than $2 \mathrm{~cm}$ observed) and (b) NRMC model for hail days reported on a longer time period.

tral parts of the GMSTWA, mostly reported from the Sydney metropolitan and Blue Mountains areas. It appears that during the longer time spans the Sydney metropolitan area received the highest number (185) of events, and Shellharbour (8) and Kiama (5) areas obtained the lowest number of hail events.

\subsection{Hail magnitude patterns}

One of the more important aspects of hail climatology is the magnitude of the hail that occur (Changnon, 1977). The magnitude of a hail matters considerably when accounting for damage such as serious injuries and severe damage to all buildings, city constructions and agricultural products. Some previous studies have concluded that most property damage begins when hail diameters are $2 \mathrm{~cm}$ or larger (Morrison, 1997). The larger the stones, typically the greater the property damage as a result. However, most losses are not linearly related to the stone sizes (Changnon et al., 2012).

The key aspect of the current research is to illustrate the hail magnitude patterns across the LGAs. Figure 11a-d present a series of maps based on an adjusted TORRO Hailstorm Intensity Scale. Comparatively, almost every region inside the GMSTWA is dominated by small hail that varies within $2-4.1 \mathrm{~cm}$. Nonetheless, a few LGAs such as Sydney metropolitan, Wingecarribee and Gosford have experienced hail of higher magnitudes. Overall, small- to medium-sized hail $(2-4.1 \mathrm{~cm})$ shows a wider distribution with a high num-

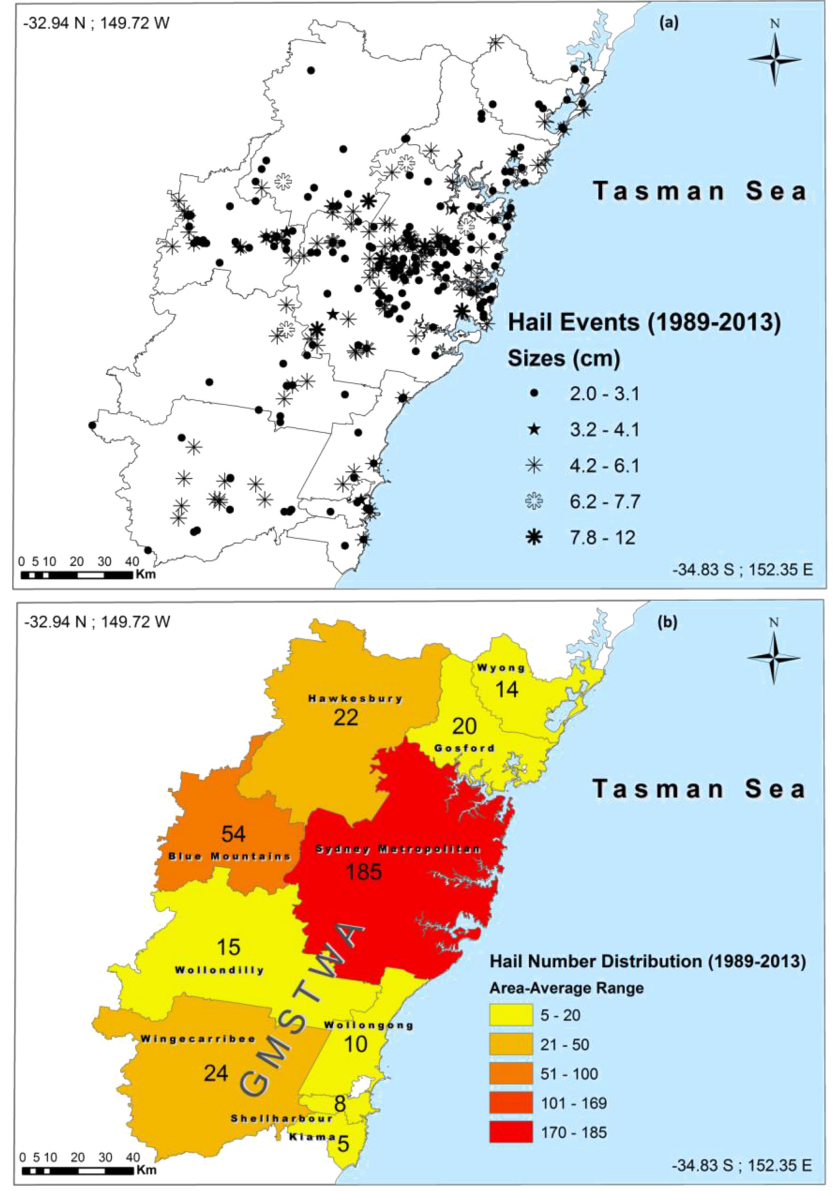

Figure 10. Spatial distribution of (a) individual hail events and (b) area-averaged hail events. The total number of hail events is also given inside of each LGA observed.

ber of stones $(72 \%)$ throughout the GMSTWA. Whereas hail of size $4.2-6.1 \mathrm{~cm}$ account for $20 \%$ of events, hail of higher magnitude $(6.2-12 \mathrm{~cm})$ contributes approximately $8 \%$ in the final areal distribution patterns.

An important finding is that as the hail magnitude increases the largest yearly hail events were observed merely inside the Sydney metropolitan area (Fig. 12a). In turn, as Fig. $12 \mathrm{~b}$ indicates, the number of hail events with the highest magnitude range reported inside the Sydney metropolitan was much higher than in the other LGAs.

Lastly, Fig. 13 presents the possible patterns for low, moderately, highly and very highly potential hazardous hail based on the available data analyzed. A raster-based distribution pattern evidently indicates that the highest potential on hail occurrence is inside the Sydney metropolitan and Blue Mountains. In the meantime, hail magnitudes over many of the LGAs appear to be at a low or moderate level. By careful inspection of hail distribution patterns, two more incidence causeways can be visually recognized: one passage curving from the southwest to the northeast and another one topping 

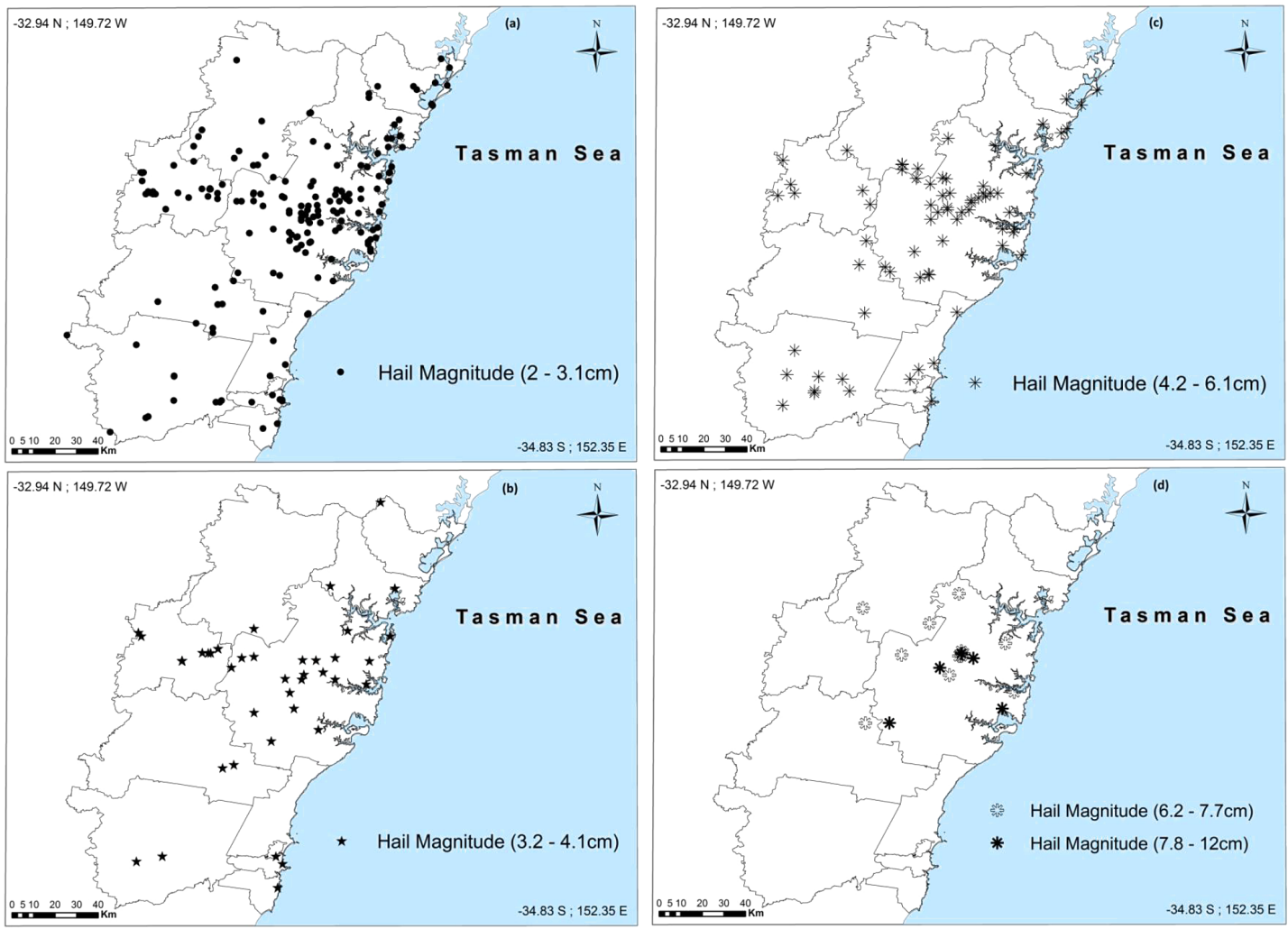

Figure 11. Spatial distribution of hail with magnitude category (a) $2-3.1 \mathrm{~cm}$, (b) $3.2-4.1 \mathrm{~cm}$, (c) $4.2-6.1 \mathrm{~cm}$ and (d) $6.2-7.7$ and $7.8-12 \mathrm{~cm}$.

some parts of the coastal districts such as Kiama, Shellharbour, Gosford and Wyong located near the Tasman Sea.

On the whole, in the context of the GMSTWA complex climatic environment, each severe hailstorm needs three main requirements for development (Whetton, 1990; Leslie et al., 2008). Moist air is a necessity because when it condenses to form cloud, heat energy is released, making the rising air more buoyant and "fueling" further hailstorm cloud growth (Andrews et al., 1996; Yeo et al., 1999). Such sources can be injected to the air masses from the nearby Tasman Sea or weather systems occasionally affecting the region (Carras and Johnson, 1982; Rasuly, 1996). An unstable atmosphere is necessary so that a developing cloud is able to rise freely to great heights in the atmosphere (Buckley et al., 2001; Deslandes et al., 2008). Besides this, initiating mechanisms are also needed as they serve as a focus for storm development. Typical mechanisms that initiate hailstorms are fronts, troughs and low-pressure systems in the regions (Speer and Geerts, 1994). As was already discussed, features of topography such as hills and mountains or dissimilar land cover may also enhance storm development (Atkinson, 1975; Shepherd and Colquhoun, 1985; Schuster et al., 2005). The severity of any subsequent hailstorms will depend largely on the buoyancy of the rising air within the supercell thunderstorm, the structure of the wind and available moisture within the atmosphere (Doswell and Brooks, 1993). All the aforementioned concepts have to be verified in future investigations, possibly through numerical modeling.

\section{Concluding remarks}

This study examined all the available hail events and their temporal-spatial characteristics by applying a climatologically oriented GIS. Unlike most previous studies that examined individual hail events over a short period in the region, the present study analyzed all the hail observations on a longer timescale based on high-quality records. It was found that hail events vary tremendously in terms of size, location, intensity and frequency of occurrence inside GMSTWA. According to the applied criteria and techniques used, the final outcomes are summarized as follows:

- Hail events are neither temporally nor spatially uniform inside the GMSTWA. They might reflect largely the impacts of climatic, environmental parameters and synoptic weather systems in the region (Kounkou et al., 2009; BoM, 2012b).

- Temporal findings indicated that most of the hail occurred predominately in afternoon and early evening, particularly in the summer months with a maximum in December. 

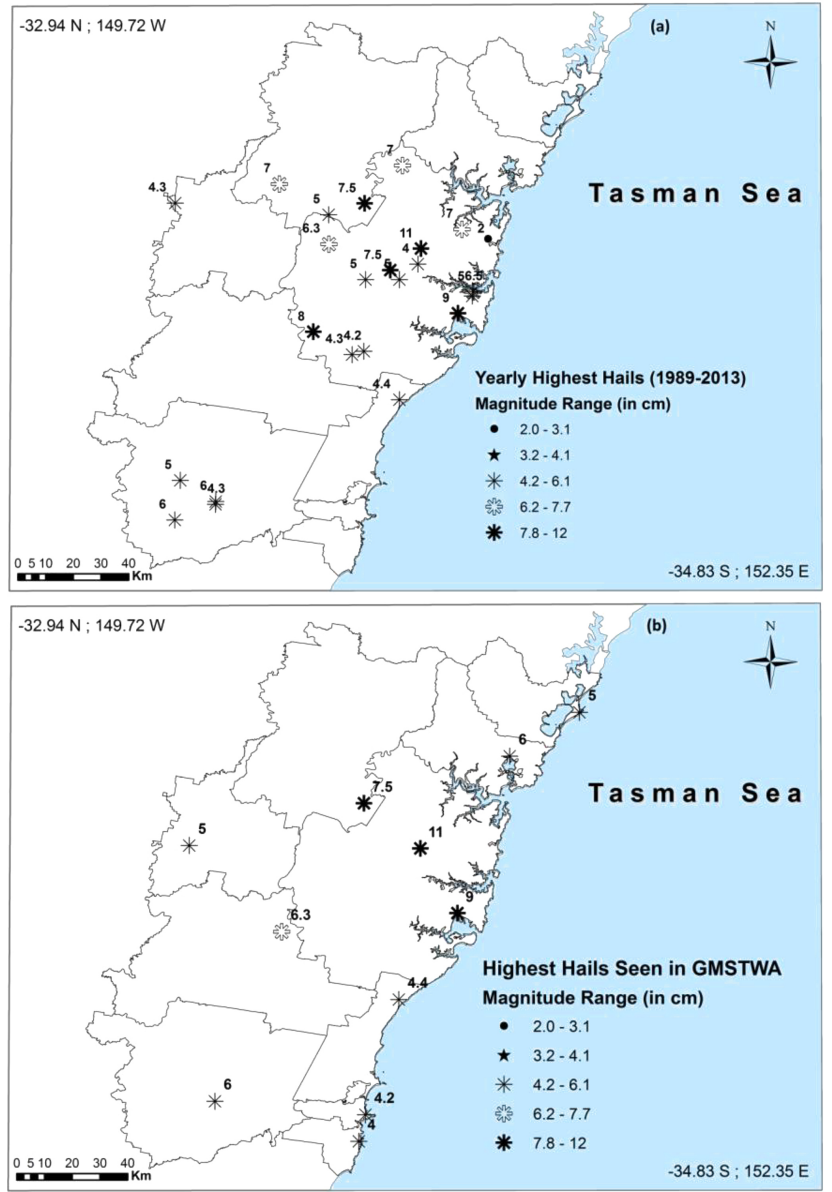

Figure 12. (a) The yearly highest hail events reported from LGAs and (b) the largest hail observed inside the GMSTWA.

- Spatial distributions established four main patterns over the study area which include the Sydney metropolitan, the topographic and the coastal effects. It was found that some of the LGAs, predominantly the Sydney metropolitan area, obtain many more destructive and super-sized hail than others. In a wide-ranging scale, the spatial distribution of hail events follows a gradient between inland and coastal areas. Their spatial appearance suggests that they are being probably controlled by the Sydney's bowl-shaped landscape arrangement. Various synoptic-scale features such as lows and fronts can be also associated with severe hailstones (Ryan, 1992; Knight and Knight, 2001).

- Lastly, some phenomena such as sea surface temperature anomalies like the El Niño Southern Oscillation may meaningfully influence the occurrence of hailstones in the region over long timescales (Yeo et al., 1999; Kuhnel, 1998; Yeo, 2005; Niall and Walsh, 2005; McBurney, 2012).

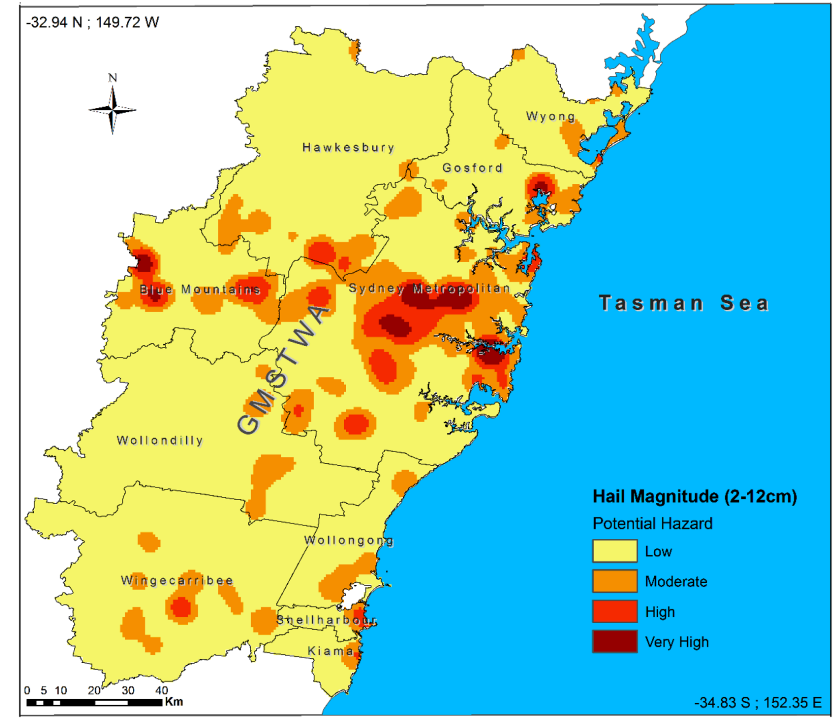

Figure 13. A raster-based hail magnitude density model inside of the GMSTWA.

- Overall patterns that emerged in the final models are in accord with the literature except the results from the temporal-spatial trend models. In the past decade, the GMSTWA has experienced less hail events and fewer destructive and super hail. However, this concluding outcome should highlight the substantial hazardous situation of the Sydney metropolitan area because the future impacts from climate variability to the hailstorm frequency and magnitude in the region need further studies, especially under an unpredictable future climate change. In any case, the information obtained here can be used in many areas such as urban planning, hail events impact preparation, risk control programs and emergency response management.

Acknowledgements. The first author (A. A. Rasuly) was partially supported by Macquarie University when he had sabbatical leave from the University of Tabriz during August 2013-April 2014. The authors would like to thank Dr. Ningbo Jiang of the NSW Office of Environment and Heritage and the other anonymous reviewer for their support and suggestions to improve the manuscript.

Edited by: A. Mugnai

Reviewed by: N. Jiang and one anonymous referee

\section{References}

Alford, P.: Thunderstorm classification. 4th Severe Thunderstorm Conference (8-12 August 1994) Australian Emergency Management Institute, Mount Macedon, Victoria, Australia, 1994.

Alford, P., Ryan, C., and Gill, J.: Thunderstorms and severe thunderstorms: a forecasting perspective. Meteorologist Course; Bureau 
of Meteorology Training Centre, 3rd Edn., Bureau of Meteorology, 1995.

Allen, J. T., Karoly, D. J., and Mills, G. A.: A severe thunderstorm climatology for Australia and associated thunderstorm environments, Aust. Meteor. Oceanogr. J., 61, 143-158, 2011.

Andrews, K. E., Blong, R. J., and Byrnes, C. H.: Wind \& hailstorms in Sydney - a thunderstorm climatology. Risk Frontiers Natural Hazards Research Centre Report, Macquarie University, 1996.

Atkinson, B. W.: The mechanical effect of an urban area on convective precipitation. Occasional Paper 3, Department of Geography, Queen Mary College, University of London, 1975.

Bahr, V. J., Kemp, R. L., and Kurzeme, D.: Report on a study of the severe thunderstorms over Sydney metropolitan area on 21 August, 1971, Aust. Govt. Pub. Service, 28 pp., 1973.

Batt, K., Hobbs, J., and Carradd, G.: Climatology of severe local storms in New South Wales, Workshop on Atmospheric Hazards, Process, Awareness and Response, University of Queensland, 20-22 September, 1995.

BoM (Bureau of Meteorology): Climatic Survey, Sydney and NSW. Australian Government Publishing Service, 1991.

BoM (Bureau of Meteorology): The Sydney Hailstorm of 18 March 1990. Phenomena Report, Bureau of Meteorology, Australia, 1993.

BoM (Bureau of Meteorology): The 21 January 1991 Sydney Severe Thunderstorm, Bureau of Meteorology, Australia, 1995a.

BoM (Bureau of Meteorology): The Storm Spotters' Handbook, Commonwealth of Australia, 1995b.

BoM (Bureau of Meteorology): Report on the 14 April Sydney Severe Hailstorm, Commonwealth of Australia, 2006.

BoM (Bureau of Meteorology): Stormy Weather, A century of storms, flood and drought in New South Wales, Australian Government, 2011.

BoM (Bureau of Meteorology): New South Wales Weather and Warnings Summary, Australian Government, 2012a.

BoM (Bureau of Meteorology): Record-breaking La Nina Events, Australian Government, 2012b.

Buckley, B. W., Leslie, L. M., and Wang, Y.: The Sydney hailstorm of April 14, 1999: Synoptic description and numerical simulation, Meteorol. Atmos. Phys., 86, 167-182, 2001.

Carras, J. N., and Johnson, G. M.: The urban atmosphere -Sydney, a case study, CSIRO, Australia, 1982.

Changnon, S. A.: Scales of hail, J. Appl. Meteor., 16, 626-648, 1977.

Changnon, S. A., Changnon, D., and Hilberg, S. D.: Hailstorms Across the Nation, An Atlas about Hail and Its Damages, Midwestern Regional Climate Centre, Illinois State Water Survey, USA, 2012.

Colquhoun, J. R.: An investigation of the severe thunderstorm at Richmond NSW on 25 December 1971. Meteorological Note 56, Bureau of Meteorology, Australia, 13 pp., 1972.

Davies, B., Logan, M., Cinque, P., Fry, G., and Leigh, R.: The Western Sydney Hailstorm 2007, Risk Frontiers Natural Hazards Research Centre, Macquarie University, 2008.

DECCW: Emergency Management Australia Disaster Database, Department of Environment, NSW Government, 2010.

Deslandes, R., Richter, H., and Bannister, T.: The end-to-end severe thunderstorm forecasting system in Australia: overview and training issues, Aust. Meteor. Mag., 57, 329-343, 2008.
Doswell, C. A. and Brooks, H. E.: Supercell thunderstorms, Weather, 48, 209-210, 1993.

EMA: Emergency Management Australia Disaster Database, http: //www.em.gov.au/Resources/Pages/DisasterDatabase.aspx (last access: 3 March 2015), July 2009.

Gatrell, A.: Density estimation and the visualization of point pattern, in: Visualization in Geographical Information Systems, edited by: Hearnshaw, H. M. and Unwin, D. J., John Wiley and Sons, New York, 65-75, 1994.

Gatrell, A., Bailey, T., Diggle, P., and Rowlingson, B.: Spatial point pattern analysis and its applications in geographical epidemiology, Trans. Institute. British Geogr., 21, 256-274, 1996.

Grace, W., Watson, A., Tepper, G., and Manson, R.: A climatology of severe thunderstorms in South Australia, Technical Report 62, Bureau of Meteorology, Melbourne, Australia, 1989.

Griffiths, D. J., Colquhoun, J. R., Batt, K. L., and Casinader, T. R.: Severe thunderstorms in New South Wales: climatology and means of assessing the impact of climate change, Clim. Change, 25, 369-388, 1993.

Hannay, A. K. and Wilson, G. U.: An analysis of thunderstorms at Sydney, Aust. Meteor. Mag., 5, 21-31, 1994.

Harper, B., Granger, K., and Hall, S.: Severe Thunderstorm Risks. Natural Hazards and the Risks They Pose to South-East Queensland, Australian Geological Survey Organisation, 15 pp., 2001.

Illian, J., Penttinen, A., Stoyan, H., and Stoyan, D.: Statistical Analysis and Modeling of Spatial Point Patterns, Wiley, London, 2008.

Johnson, R. W., Blong, R. J., and Ryan, C. J.: Natural hazards: Their Potential in the Pacific Southwest, Australian Geological Survey Organization, Australia, 1995.

Knight, C. A. and Knight, N. C.: Hailstorms. Chapter 6 in Severe Convective Storms, in: Meteorological Monograph, edited by: Doswell, C. A., Am. Meteor. Soc., 28, 223-254, 2001.

Kounkou, R., Mills, G., and Timbal, B.: A reanalysis climatology of cool-season tornado environments over southern Australia, Int. J. Climatol., 29, 2079-2090, 2009.

Kuhnel, I.: The use of multifactor southern oscillation index for the estimation of annual hailstorm frequencies in the Sydney area, Int. J. Climatol., 18, 841-858, 1998.

Kuleshov, Y., de Hoedt, G., Wright, W., and Brewster, A.: Thunderstorm distribution and frequency in Australia, Aust. Meteor. Mag., 51, 145-154, 2002.

Lauren, M. S. and Mark, V. J.: Spatial Statistics in ArcGIS, ESRI, Redlands, USA, 2010.

Leigh, R. and Kuhnel, I.: Hailstorm loss modelling and risk assessment in the Sydney region, Australia, Nat. Hazards, 24, 171-185, 2001.

Leslie, L. M., Leplastrier, M., and Buckley, B. W.: Estimating future trends in severe hailstorms over the Sydney Basin: A climate modelling study, Atmos. Res., 87, 37-51, 2008.

Linacre, E. T. and Hobbs, J.: The Australian Climatic Environment, John Wiley and Sons, Brisbane, Australia, 1977.

Matthews, C.: The Sydney severe thunderstorm of 20 November 1994, Proceedings of the Fifth Australian Severe Thunderstorm Conference, 28 July-2 August 1996, Avoca Beach, New South Wales, 178 pp., 1996.

Matthews, C. and Geerts, B.: Characteristic thunderstorm distribution in the Sydney area, Aust. Meteor. Mag., 44, 127-138, 1995. 
McBurney, B.: Meteorological Parameters Controlling Hailstorm Development in the Sydney Metropolitan Region, Honours Degree Dissertation, Macquarie University, 100 pp., 2012.

McMaster, H.: Hailstorm risk assessment in rural New South Wales, Nat. Hazards, 24, 187-196, 2001.

Middelmann, M. H. (Ed.): Natural Hazards in Australia, Identifying Risk Analysis Requirements, Geoscience Australia, Department of Industry, Tourism and Resources, Canberra, 2007.

Mitchell, A.: The ESRI Guide to GIS Analysis, Vol. 2, ESRI Press, USA, 2005.

Mitchell, E. D. and Griffiths, D. J.: Report on the Sydney Hailstorm March 1990, Bureau of Meteorology, Melbourne, Australia, 1993.

Morgan, P. A.: The Sydney Severe Thunderstorms of 10 November, 1976, Meteorological Note 96, Bureau of Meteorology, Sydney, Australia, 1979.

Morrison, S.: Causes and extent of damage related to structure, material, and architectural failure, Hail, Hail the Disaster's Here, Employers Reinsurance Corp. Overland Park, KS, 12 pp., 1997.

Natural Disasters Organisation: Commonwealth Counter Disaster Concepts and Principles, Australian Counter Disaster Handbook, Vol. 1, 1989.

Niall, S. and Walsh, K.: The impact of climate change on hailstorms in south-eastern Australia, Int. J. Climatol., 25, 19331952, 2005.

Rasuly, A. A.: Temporal and Spatial Study of Thunderstorm Rainfall in the Greater Sydney Region, School of Geosciences, University of Wollongong, PhD Thesis, 532 pp., 1996.

Rasuly, A. A.: An Analytic Approach to GIS Technology, Tabriz University Press, Tabriz, 2005.

Rasuly, A. A. and Cheung, K.: Spatial Distribution of Severe Thunderstorm Rainfall Events throughout the GMSTWA \& Adjacent Tasman Sea, Abstracts of the 7th Annual CAWCR Workshop, Observing, Estimating and Forecasting Rainfall: From Science to Applications, 21-23 October, Melbourne, Australia, 2013.

Ryan, C. J.: Dynamical Classification of Australian Thunderstorms, Meteorological Study No. 40, Bureau of Meteorology, Australian Government Publishing Service, Canberra, 1992.

Schuster, S., Blong, R., and Speer, M.: A hail climatology of the greater Sydney area and New South Wales, Australia, Int. J. Climatol., 25, 1633-1650, 2005.
Scott, D. W.: Multivariate Density Estimation, Theory, Practice and Visualization, Wiley, New York, 1992.

Scott, L. and Getis, A.: Spatial statistics, in: Encyclopaedia of Geographic Informations, edited by: Kemp, K., Sage, Thousand Oaks, Canada, 2008.

Scott, T. S., Graffman, I., and Ingram, J.: GIS applications in climate and meteorology. ESRI International User Conference, 2000.

Shepherd, D. J. and Colquhoun, J. R.: Meteorological aspects of an extraordinary flash flood event near Dapto, NSW, Aust. Meteor. Mag., 33, 87-102, 1985.

Silverman, B. W.: Density Estimation for Statistics and Data Analysis, Chapman and Hall, New York, 1986.

Spark, E. and Casinader, T.: The 21 January 1991 Sydney Severe Thunderstorm, Bureau of Meteorology, Australian Government, 1995.

Speer, M. S. and Geerts, B.: A synoptic mesoalpha-scale climatology of flash floods in the Sydney Metropolitan area, Aust. Meteor. Mag., 43, 87-103, 1994.

Sumner, G. N.: Seasonal change in the distribution of rainfall over the Great Dividing Range: general trends, Aust. Meteorol. Magazine, 31, 121-130, 1983.

Tucker, D. F.: Characteristics of severe hail events in eastern Australia, 21st conference on Severe Local Storms, 12-16 August, University of Kansas, 2002.

Webb, J. D. C., Elsom, D. M., and Meaden, G. T.: The TORRO hailstorm intensity scale, J. Meteor., 11, 337-339, 1986.

Whetton, P. H.: Relationships between monthly anomalies of Australian region sea-surface temperature and Victorian rainfall, Aust. Meteor. Mag., 38, 31-41, 1990.

Yeo, C.: Severe thunderstorms in the Brisbane region and a relationship to the El Nino Southern Oscillation, Aust. Meteorol. Mag., 54, 197-202, 2005.

Yeo, S., Leigh, R., and Kuhnel, I.: The April 1999 Sydney Hailstorm, Aust. J. Emer. Man., 14, 23-25, 1999.

Zillman, J.: Report by the Director of Meteorology on the Bureau of Meteorology's forecasting and warning performance for the Sydney hailstorm of 14 April 1999. Bureau of Meteorology, Melbourne, 1999. 